\title{
THE GERM THEORY, BERIBERI, AND THE DEFICIENCY THEORY OF DISEASE
}

\author{
by
}

\section{K. CODELL CARTER*}

BY THE BEGINNING of the twentieth century, many diseases could be causally explained by the germ theory. However, other important diseases defied every attempted explanation. One such disease was beriberi which, in some groups, was responsible for more deaths than were all the infectious illnesses combined. ${ }^{1}$ To explain how beriberi was caused, a new theory of disease was developed, the deficiency theory.

Historical accounts consistently treat the germ theory as an obstacle that delayed progress on the deficiency theory of disease. Ihde and Becker claim that "the germ concept proved a major barrier to the recognition and study of deficiency diseases."2 C. P. Stewart writes, "one factor which undoubtedly held up the development of the concept of deficiency diseases was the discovery of bacteria in the nineteenth century [sic] and the consequent preoccupation of scientists and doctors with positive infecting agents in disease."3 Numerous writers assert that the deficiency concept was difficult to accept because the germ theory suggested that only a positive agent (such as a micro-organism or a toxin) could cause something. ${ }^{4}$ In his excellent history of nutrition, E. V. McCollum notes that "improved microscopes and the staining and other

*K. Codell Carter, Ph.D., Chairman, Department of Philosophy, Brigham Young University, Provo, Utah 84601, U.S.A. (I would like to thank the Brigham Young University for financial support in the form of a Professional Development Leave.)

${ }^{1}$ For example, in the Japanese Navy between 1876 and 1883, deaths from beriberi regularly constituted about half the total deaths from all causes. (Kamehiro Takaki, 'The preservation of health amongst the personnel of the Japanese Navy and Army', Lancet, 1906, i: 1369-1374, 1451$1455,1520-1523$, p. 1369). At the turn of the century, half the total deaths among Chinese labourers in the Malay peninsula were from beriberi. (W. Leonard Braddon, The cause and prevention of beriberi, London, Rebman, 1907, pp. 1-4.)

2 Aaron J. Thde and Stanley L. Becker, 'Conflict of concepts in early vitamin studies', J. Hist. Biol., 1971, 4: 1-33, p. 16; Richard H. Follis, jr. takes the same view in 'Cellular pathology and the development of the deficiency disease concept', Bull. Hist. Med., 1960, 34: 291-317.

' C. P. Stewart, 'Scurvy in the nineteenth century and after', in C. P. Stewart and Douglas Guthrie (editors), Lind's Treatise on Scurvy, Edinburgh, Edinburgh University Press, 1953, p. 408.

- Here is a sample: "The evidence from disease would have led sooner to a conception of these food constituents and their functions but for a not unnatural bias in thought. It is difficult to implant the idea of disease as due to deficiency. Disease is so generally associated with positive agents-the parasite, the toxin, the materies morbi-that the thought of the pathologist turns naturally to such positive associations and seems to believe with difficulty in causation prefixed by a minus sign." (Medical Research Committee, Report on the present state of knowledge concerning accessory food factors (vitamines), Special Report No. 38, London, H.M.S.O., 1919, p. 2.) The same idea is expressed by Leslie J. Harris, Vitamins in theory and practice, 4th ed., Cambridge, Cambridge University Press, 1955, p. 6; by Stewart, op. cit., note 3 above, p. 408; and by Follis, op. cit., note 2 above, p. 307. 


\section{K. Codell Carter}

technics applicable to the study of the problems of pathology so monopolized the attention of investigators that they had little incentive to consider any aspect of malnutrition as a cause of disease."5 In Toward the conquest of Beriberi, Robert R. Williams treats the germ theory only as the source of one false explanation for the etiology of beriberi. ${ }^{6}$

These accounts overemphasize the extent to which the germ theory obstructed development of the deficiency concept, and they entirely ignore important ways in which the germ theory contributed positively to the deficiency theory of disease. By taking account of these contributions we can better understand the relation between the two theories.

\section{I}

In the early nineteenth century, scurvy and rickets were generally believed to be diet-related. In 1830 the Lancet contained a series of 'Clinical lectures' by John Elliotson, Professor of Medicine in University College, London. In discussing scurvy, Elliotson noted that "the cause . . . is always, I believe, a want of fresh animal and fresh vegetable food." "About seven years later, in a similar lecture, Marshall Hall observed "scorbutus is generally induced by a deficiency of fresh vegetable food. It is also occasionally referred to other errors in diet, to the respiration of a crowded or otherwise impure atmosphere, to excessive fatigue, anxiety, etc. ... The prevention and cure of scorbutus consists in the administration of fresh [animal?] and vegetable food, and, above all, of citric acid."8 Both men refer to Gilbert Blane and to James Lind whose works were, by that time, the recognized sources on scurvy. ${ }^{9}$ Neither Elliotson nor Hall suggests that his views are new or atypical; indeed, both men acknowledged that lemon juice had been the standard cure for scurvy for more than 200 years.

In 1840 George Budd summarized clinical knowledge of scurvy in an article in Alexander Tweedie's $A$ system of practical medicine. ${ }^{10}$ Budd discussed various fruits and vegetables that were generally known to cure scurvy. Knowing of François Magendie's experiments demonstrating the inadequacy of certain macronutrients, ${ }^{11}$ Budd speculated that "the study of organic chemistry and the experiments of physiologists" would ultimately shed light on the essential element common to the antiscorbutic plants. ${ }^{12}$ Two years later, a series of Budd's lectures was published in which he clearly and explicitly classified scurvy, rickets, and certain eye disorders as

- Elmer Verner McCollum, A history of nutrition, Boston, Houghton Mifflin, 1957, pp. $225 f$.

- Robert R. Williams, Toward the conquest of beriberi, Cambridge, Mass., Harvard University Press, 1961, pp. 13-15, 18f, 35.

'John Elliotson, 'Clinical lectures', Lancet, 1830-1, i: 650-655, p. 651.

- Marshall Hall, 'Lectures on the theory and practice of medicine', ibid., 1837-8, ii: 851.

- Lind's Treatise on scurvy was published in 1753; Blane published Observations on the diseases incident to seamen in 1785. Substantial selections from both works are reprinted in C. Christopher Lloyd, The health of seamen, London, Naval Records Society, 1965, pp. 1-211.

10 George Budd, 'Scurvy', in Alexander Tweedie (editor), A system of practical medicine, London, Whittaker, 1840, vol. 5, pp. 58-95. Subsequent volumes of Tweedie's work appeared under the title The library of medicine, and later writers generally referred to the whole work by that title.

21 For an account of Magendie's experiments see McCollum, op. cit., note 5 above, pp. 75-79.

12 Budd, op. cit., note 10 above, p. 77. 


\section{The germ theory, beriberi, and the deficiency theory of disease}

diseases resulting from dietary deficiencies. ${ }^{13}$ Budd's 1840 article on scurvy was frequently cited by English physicians through the turn of the century. ${ }^{14}$ One reason for his continued influence was that he was among the last practising physicians to be particularly interested in the disease. By the beginning of the nineteenth century, scurvy had been virtually eliminated from the British navy. ${ }^{15}$ Except for uncontrollable situations, such as famine and war, where the known therapies could not be applied, scurvy gradually declined in other areas and populations. ${ }^{16}$ Moreover, the prevailing conception in medical circles was that a given disease was identical with a particular collection of symptoms. ${ }^{17}$ Given this conception, and given that the symptoms of scurvy were more readily controlled than were those of most other diseases, ${ }^{18}$ scurvy

13 George Budd, 'Disorders resulting from defective nutriment', Lond. med. Gaz., 1842, ii: 632-636, 712-716, 743-749, 825-831, 906-915. In a recent publication, R. Elwyn Hughes claims that Budd "introduced .... into nutritional thought the concept that a specific disease could result from the absence of a single dietary component" and that while fresh foods were recognized as beneficial in preventing and curing scurvy "there is no evidence that writers previous to Budd regarded a dietary lack . . . as the sole - or even as a necessary - cause of [scurvy]." ("George Budd (1808-1882) and nutritional deficiency diseases', Med. Hist., 1973, 17: 127-135, pp. 128f.) Compare these claims with the following quotation from John Elliotson, published ten years before Budd's articles: "Scurvy is a disease ... purely chemical. The body, structure, and functions are not in the least at fault; in one sense, each part of the system is ready to perform all its functions, but one of the external things necessary for its doing so is taken away. In the case of suffocation, the body is not at all in fault, but it suffers from a want of fresh air; so in scurvy, the functions are all right, but the food which the body by nature requires, is withheld from it." (Elliotson, op. cit., note 7 above, p. 653.)

14 Hughes (op. cit., note 13 above, p. 133) observes "there is no strong evidence that [Budd's] ideas achieved any element of permanency or influence" although Hughes admits that Budd was cited by Pereira in his Treatise on food and diet (1843). In fact, Budd's work on scurvy was cited (with approval) in a major review of literature on scurvy (Brit. For. med.-chir. Rev., 1848, ii: 439-474, p. 441); by various writers in the Lancet $(1848$, i: $603 ; 1860$, ii: $428 ; 1877,1: 869)$; in the articles on scurvy in the first editions both of Osler and McCrae ( $A$ system of medicine, London, Hodder \& Stoughton and Oxford University Press, 1907, vol. 1, p. 893) and of Allbutt and Rolleston (A system of medicine, London, Macmillan, 1909, vol. 5, p. 897); and by the Medical Research Committee (op. cit., note 4 above, p. 58). Hughes (op. cit., note 13 above, p. 131) writes that Budd's "concept of accessary dietary principles and of associated deficiency diseases, stood in almost complete isolation from the mainstream of mid-nineteenth-century nurtitional thought." All but the last of the preceding sources take Budd as very much in the mainstream of mid-nineteenth-century thought on scurvy. In view of these sources, and of the comments by Elliotson and Hall cited above, Budd's writings on scurvy must be viewed as a knowledgeable and moderately influential statement of the commonly held opinions of his day.

${ }^{15}$ Sheldon F. Dudley, 'The Lind tradition in the Royal Naval Medical Service', in Stewart and Guthrie, op. cit., note 3 above, pp. 369-386.

16 Stewart, op. cit., note 3 above, pp. 404-412; August Hirsch, Handbuch der historisch-geographischen Pathologie, 2nd ed., Stuttgart, Ferdinand Enke, 1883, vol. 2, pp. 363-374.

${ }^{17}$ A particularly clear illustration of this conception is in J. A. Symonds, 'Pathological introduction', in Tweedie, op. cit., note 10 above, vol. 1, pp. 2f. Symonds writes that the word "disease" denotes "a collection of disordered actions, called symptoms". Later he observes that "morbid actions or phenomena may occur singly; but far more frequently they are observed in certain groups. The latter are what are generally known as special diseases, and are the subjects of nosology. The individual affections composing the groups are called symptoms ... which are themselves instances of disease. Thus the disease called phthisis is a collection of morbid states, such as emaciation, hectic fever, cough, expectoration, etc.; these are it symptoms: none of them individually could be called phthisis-a name which only belongs to them collectively."

18 Gilbert Blane wrote that the efficacy of lemon juice in curing scurvy "may . . . be stated as singular when compared to that of any other remedy in any other disease." Since it prevents and cures the disease so completely and with no adverse effects, "it performs not only what no other remedy will perform in this disease, but what no known remedy will effect in any known disease whatever." Observations on the diseases incident to seamen, in Lloyd, op. cit., note 9 above, pp. $179 f$. 


\section{K. Codell Carter}

must have been commonly regarded as completely understood. This attitude is typified in an editorial written in 1858 wherein the conquest of scurvy is spoken of as a leaf in the laurel wreath on the brow of medical science. ${ }^{10}$

One can gauge the attitude of nineteenth-century British physicians toward scurvy by examining references to the disease in the articles, editorials, and letters in the Lancet. After Budd's articles there are few references to scurvy until 1848 when failure of the potato crop resulted in numerous cases of the disease in England and Ireland. Work carried out at this time by John Aldridge and (independently) by Alfred B. Garrod suggested that scurvy may have been caused by a deficiency of potash. ${ }^{20}$ Through the next decade there are few references to the disease. Beginning in the late 1850s and continuing for about twenty years there are numerous letters and editorials decrying the continued appearance of scurvy in the British merchant fleet. In these notices, scurvy is consistently treated as a disease entirely understood and completely preventable-ship owners who allow the disease to appear are regarded as criminal and, in one editorial, compared with murderers. ${ }^{21}$ In one of the few original articles on scurvy to appear in this period, the disease is attributed to deficiency of protein. ${ }^{22}$ Fifteen years later, in another original article, we read that "... no fact in medicine is more clearly established than that the exclusive cause of scurvy is the prolonged and complete withdrawal of succulent plants and fruits. ..."23 By the 1880 s scurvy is treated as a medical curiosity of which very few practising physicians have had immediate experience. ${ }^{24}$ In that period, however, letters and editorials begin to take account of the experiences of certain arctic explorers who had survived for months on fresh uncooked meat with no sign of scurvy. ${ }^{25}$ The chief question in these writings is whether the dietary deficiency that results in scurvy could be corrected by fresh meat as well as fresh vegetables. ${ }^{26}$ By 1883 some microbiologists were arguing that scurvy was caused by micro-organisms, ${ }^{27}$ but the first hint of these arguments to appear in the Lancet was in 1886. In that year, a brief editorial mentions research by the Russian pathologist, T. Stazevich, who argued that scurvy was a "form of septic poisoning". ${ }^{28}$ Until that time the Lancet contains no suggestion whatsoever that scurvy is anything other than a nutritional deficiency disorder. In 1889 Wilhelm Koch published an ambitious study of blood diseases in which he argued that scurvy, haemophilia, and various other disorders were variant forms of an infectious blood disease, and that the obvious correlation between scurvy

10 Lancet, 1858, i: 145.

${ }^{20}$ McCollum (op. cit., note 5 above, p. 254) and most other historians attribute this view to Garrod. Apparently, however, Aldridge deserves the dubious honour of having originated this particular misconception two years before Garrod. For Aldridge's claim to priority and references to the original publications see Lancet, 1862, ii: 268.

21 Ibid., 1858, i: 146.

22 W. S. Oliver, 'Scurvy: its cause', ibid., 1863, i: 61.

23 Charles Henry Ralfe, 'General pathology of scurvy', ibid., 1877, i: 868-871, p. 869.

24 Ibid., 1880, i: 992; 1882, i: 1048.

${ }^{25}$ For some examples see ibid., 1882, ii: 329f; 1904, ii: 1659.

26 The conclusion was that "a diet of perfectly fresh animal food will supply the deficiencies and will check the spread of the disease." Ibid., 1904, ii: 1660.

${ }^{27}$ For a survey of the early literature see August Hirsch, Handbook of geographical and historical pathology, trans. by C. Creighton, London, New Sydenham Society, 1885, vol. 2, pp. 558-561.

${ }^{28}$ Lancet, 1886, i: 1036 


\section{The germ theory, beriberi, and the deficiency theory of disease}

and the lack of fresh food (like the hereditary pattern of haemophilia) could be explained on this interpretation. ${ }^{29}$ Koch's book seems not to have had much impact, but it was given a serious review in the Lancet ${ }^{30}$ Through the end of the century, there are scattered references to toxic and micro-organistic explanations for scurvy; these are generally sceptical and often rebutted. ${ }^{31}$ In the first decade of the twentieth century opinion was clearly shifting toward such an explanation, but as late as December 1904, an editor of the Lancet could still write that "the general disposition is to regard scurvy as due to the absence of certain elements in the food which is taken, but the exact nature of those elements has not been conclusively demonstrated."32

The preceding quotation is part of a continuous tradition that, as we have seen, extends back beyond the time of George Budd. This quotation was published less than three years before the classic paper on scurvy by Holst and Frölich that was fundamental to the development of the deficiency theory ${ }^{33}$ and less than eight years before that theory was given its first full articulation by Casimir Funk. ${ }^{34}$ Yet in 1911, seven years after the editorial quoted above, a report on vitamins published by the British Medical Research Committee stressed the difficulty of implanting "the idea of disease as due to deficiency". ${ }^{35}$ Ironically, this report contains a reference to Budd's work on scurvy and commends his treatment of the history of the disease. ${ }^{36}$ In 1932 a second report by the Medical Research Council retained the language about the difficulty of thinking of negative causes, dropped the reference to Budd, and added a note indicating that "it is now difficult to understand how . . . scurvy failed in practical medicine to obtain recognition as a disease due to a deficiency in food." 37 The greatest difficulty is in understanding how these false traditions could have gained influence so quickly. ${ }^{38}$

There can be no doubt that development of the germ theory captivated the interests of medical researchers during the latter part of the nineteenth century. "With the work of Pasteur and Koch, ... there penetrated rapidly into all fields of medicine the idea that infinitely small beings, endowed with special pathogenic qualities, played a pre-eminent role in producing many diseases. The new concept made such a great

${ }^{29}$ Wilhelm Koch, Die Bluterkrankheit in ihren Varianten, Stuttgart, Ferdinand Enke, 1889.

${ }^{30}$ Lancet, 1890, i: 1186f, and cf. the interesting response pp. $1272 \mathrm{f}$.

${ }^{31}$ For examples see ibid., 1900, ii: 321f, 589f, and 1164.

32 Ibid., 1904, ii: 1660 (my italics). In 1907 a letter printed in Br. med. J. (i: 683) bemoans the fact that "the theory that want of fresh vegetable causes scurvy dies very hard", and the author then goes on to argue that fresh meat will also supply the necessary nourishments.

${ }^{23}$ Alex Holst and Theodor Frölich, 'Experimental studies relating to ship-beriberi and scurvy, part II', J. Hyg., Camb., 1907, 7: 634-671.

34 Casimir Funk, 'The etiology of the deficiency diseases', J. St. Med., 1912, 20: 341-368.

${ }^{25}$ Medical Research Committee, op. cit., note 4 above, p. 2.

${ }^{83}$ Ibid., p. 58.

${ }^{37}$ Medical Research Council, Vitamins: a survey of present knowledge, London, H.M.S.O., 1932, p. 14. Six years later, Budd was rediscovered by Leslie J. Harris and hailed as a prophet. Vitamins in theory and practice, Cambridge, Cambridge University Press, 1938, p. 8.

${ }^{38}$ The inadequate historical perspective of influential researchers was an important factor. In reviewing early advocates of the deficiency concept, Holst and Frölich refer to James Lind (who was one of the few early British authorities who failed to identify scurvy unequivocally as a deficiency disease) and August Hirsch, and to various reports by observers of particular occurrences of the disease. (Holst and Frölich, op. cit., note 33 above, pp. 666-669). There is no recognition of the one-hundred-year tradition in British practical medicine in which scurvy had been regarded consistently and almost unanimously as a deficiency disease. 


\section{K. Codell Carter}

impression that for a while it was believed that the cause of all diseases could be ascribed to microbes alone .... Almost completely dominant, bacteriology at this period became the centre and goal of medical investigations." ${ }^{39}$ However, serious original work on scurvy had ceased decades earlier. Through the nineteenth century, practising physicians saw fewer and fewer cases of scurvy; medical interest in the disease declined accordingly. In this period, the few organic chemists and physiologists who investigated human nutrition showed almost no interest in the disease. ${ }^{40}$ By 1880 common medical opinion was that microbiology was the most promising new field for medical research, but, at least in England, physicians also believed that scurvy was a well-understood nutritional disorder that held little practical or theoretical interest. Under these circumstances it seems misleading (if not false) to speak of the germ theory as a serious obstacle to the recognition and study of scurvy as a nutritional disease. Indeed, the germ theory provided the incentive to reopen investigation of the disease as researchers sought to explain scurvy as yet another manifestation of parasitic infection. It was into this context-a context in which medical research was dominated by the germ theory-that beriberi rapidly achieved prominence.

\section{II}

Beriberi seems to have been known to oriental writers as early as the second century; ${ }^{41}$ the earliest descriptions in western literature are from the seventeenth century. ${ }^{42}$ Prior to the nineteenth century, the disease was relatively unimportant even in the orient. This is evident, first, from the treatment the disease received in prenineteenth-century medical literature, and second, from the fact that modern steammilling procedures, which we now recognize to have been substantially responsible for the rise of beriberi, did not become common in Asia until then. ${ }^{43}$ By the last quarter of the nineteenth century the disease was widespread and growing at an extraordinary rate. It is difficult to gauge accurately the growth of beriberi; we must be content with a few scattered hints. (1) In the Japanese Army in 1876 there were 3,868 cases of beriberi among 35,300 men ( 11 per cent), in 1877 there were 2,687 cases among 19,600 men (14 per cent), and in 1878 there were 13,629 cases among 36,100 men ( 38 per cent).44 This percentage remained roughly constant through 1884 and then it declined because of dietary reforms, but during the war between Japan and Russia (1904-1905) there were nearly 200,000 cases of beriberi. ${ }^{45}$ (2) In thirty-one specific district hospitals in the

" Arturo Castiglioni, A history of medicine, 2nd ed., trans. by E. B. Krumbhaar, New York, Alfred A. Knopf, 1947, p. 809.

10 The most important exceptions are Alfred B. Garrod (cited in note 20 above) and Theobald Smith who, in 1895, induced scurvy in animals, apparently without realizing what he had achieved. (McCollum, op. cit., note 5 above, p. 255.) Even Holst and Frölich did not set out to study scurvy, and they evidently experienced some surprise when their test animals showed unmistakable symptoms of that disease. Important research was carried out in nutrition during the nineteenth century, but it did not concern micronutrients in any direct way. (McCollum, op. cit., note 5 above, pp. 84-134, 201-207.)

11 Hirsch, op. cit., note 27 above, pp. 572f.

42 Ralph H. Major, Classic descriptions of disease, 2nd ed., Springfield, Ill., Charles C Thomas, 1939 , pp. 661-665.

a Franklin Bicknell and Frederick Prescott, The vitamins in medicine, 3rd ed., London, William Heinemann Medical Books, 1953, p. 183.

“ B. Scheube, Die Beriberikrankheit, Jena, Gustav Fischer, 1894, p. 14.

ss G. Shibayama, 'Some observations concerning beriberi', Philipp. J. Sci., 1910, 5: 123. Takaki 


\section{The germ theory, beriberi, and the deficiency theory of disease}

Malay peninsula, Chinese patients admitted for beriberi increased from 1,206 in 1881 to 3,175 in 1891 , and to 6,767 in 1901 . In that period, beriberi accounted for more than 100,000 deaths among Chinese labourers in the Malay States-over half the total death rate for that population. ${ }^{46}$ (3) In 1883 August Hirsch reported that within the preceding twenty years, beriberi had appeared in many areas for the first time (e.g. lower Bengal, Ceylon, Africa, and Brazil), and that it was epidemic in coastal areas of Japan and of other Asian countries. ${ }^{47}$ Ten years later, B. Scheube reported that the disease had recently appeared for the first time in Siam and in the Philippines, that it was spreading in Africa and in South America, and that it was now endemic throughout Japan. ${ }^{48}$ In 1907, Patrick Manson gave the disease a more extensive distribution (e.g. he states that it is common in southern China where, according to Hirsch and Scheube, it was formerly rare), and in most areas incidence of the disease seems to have increased. ${ }^{49}$ Finally, (4) one can gain some appreciation for the remarkable rise in the disease by surveying the professional literature of the period. Scheube's nearly complete bibliography includes two publications on beriberi between 1800 and 1809; in subsequent decades the publications numbered eight, ten, eleven, thirty, sixty-four, eighty, and between 1880 and 1889 , one hundred and eighty-one. ${ }^{50} \mathrm{~W}$. Leonard Braddon's incomplete bibliography lists nearly two hundred articles and books for the decade from 1890 to 1899; another incomplete bibliography lists two hundred and fifty publications for the period from 1900 to $1910 . .^{51}$ A complete bibliography for this period alone would certainly approach five hundred items. Writers in the late 1870 s still regarded beriberi as an exotic and unfamiliar topic. ${ }^{52}$ About thirty years later, an editorial in the Lancet begins with the observation that "there is probably no disease concerning which so much discussion as to its etiology has taken place as beriberi."53

We can, somewhat arbitrarily, take 1880 as the beginning of serious occidental interest in beriberi. By that time there was a strong and broadly based opinion that the disease was diet-related. It was obvious to everyone that the disease was predominant only in areas where rice was the staple diet. Several medical obesrvers between 1850 and 1880 attributed the disease to an "insufficient diet or a diet not corresponding to the metabolisms and bloodmaking, or to the needs of the body". ${ }^{54}$ Of those who ascribed beriberi to an insufficient diet, some seem to have believed that it was simply a quan-

(op. cit., note 1 above, p. 1521) gives figures for the years 1878-1884, and lists 97,572 cases of beriberi for the Russian war. Interestingly enough, during the war the Russian Army seems not to have suffered a single case of beriberi.

4 Braddon, op. cit., note 1 above, pp. 1-4, 513-521.

${ }^{47}$ Hirsch, op. cit., note 27 above, pp. 573-578.

${ }^{48}$ Scheube, op. cit., note 44 above, pp. 10-16.

'Patrick Manson and C. W. Daniels, 'Beriberi', in Allbutt and Rolleston, op. cit., note 14 above, vol. 2, part 2, pp. 615-643.

so Scheube, op. cit., note 44 above, pp. 207-218.

s1 Schaumann, 'Die Ätiology der Beriberi', Arch. Schiffs- u. Tropenhyg., 1911, 14: Beiheft 8: 375-385.

${ }^{52}$ In 1876 William Anderson, who claimed to be the second European to write on beriberi in Japan (kakke), began his article by observing that this topic is "almost entirely new to the European medical world". ('Kakke', St Thom. Hosp. Rep., 1876, 7: 5-30.) Four years later, J. Rupert observed that beriberi is a disease known to Europeans by name only. 'Uber Beriberi', Dt. Arch. klin. Med., 1880, 27: 95-110, 499-519, p. 95.)

sa Lancet, 1911, ii: 842.

st Hirsch, op. cit., note 27 above, p. 589. 


\section{K. Codell Carter}

titative failure-people who got beriberi were those who had too little to eat. ${ }^{55}$ However, others believed that the problem was a qualitative failure-those who contracted the disease had too little of certain essential foods. Van Leent, for example, held that beriberi was always due to consumption of too small a proportion of albuminous substance and of fat. ${ }^{56}$ Among the most important early observers to espouse a dietary explanation for beriberi was Kamehiro Takaki. Takaki was the first person to collect systematic evidence on a large scale that supported the deficiency concept. He first heard of beriberi from his father who was a guard at the Japanese Imperial Palace. Many of the guards suffered from beriberi; "they attributed the cause to food and called a provision box the "beriberi box'."57 Takaki became a naval doctor, spent five years studying medicine in London, and was appointed director of the Tokyo Naval Hospital. By 1882 Takaki's own observations led him to attribute beriberi to poor diet. His view was that "a wide departure of nitrogen and carbon from the standard proportion (1 to 15$)$ essential to the maintenance of health, resulting from a great deficiency of nitrogenous substances and a great excess of carbohydrates in food, is the cause of kakke (beriberi)." "58 Takaki persuaded the sceptical Japanese admiralty to initiate massive dietary reforms-crews were given more meat (especially fresh meat), more vegetables, and at some meals they were given barley instead of rice. The effects were incredible: in 1882 there were over 400 cases of beriberi for each 1,000 men, in five years the disease had been completely eliminated. Takaki's observations were reported in major European medical periodicals, he himself was honoured at home and abroad, and his evidence was ultimately important for the solution of beriberi. Unfortunately, Takaki's own ideas about the etiology of beriberi were false and he seems to have persuaded almost no-one. ${ }^{59}$

Takaki's theory was conclusively refuted by a large, if unsystematic, body of epidemiological facts that were widely known years before his studies were even

sb Ibid., p. 590. This idea was rejected on the grounds that those who contracted beriberi often consumed prodigious quantities of rice.

so Van Leent, 'Mededeelingen over beriberi', Geneesk. Tijdschr. Ned.-Indië, 1880, 20: 272.

s7 Takaki, op. cit., note 1 above, p. 1370.

${ }^{88}$ Takaki, 'On the cause and prevention of kakke', Sei-i-Kwai med. J., 1885, 4: 29. Other writers favoured the idea that beriberi was due to deficiency of fat. For a brief review of some work done along this line see Br. med. J., 1899, ii: 487, 866.

so It is difficult to identify anyone who espoused Takaki's theory, although his dietary reforms were emulated (e.g. in the British prison at Kuala Lumpur). Early European reviews of Takaki's results generally rejected his theory. In the Lancet, the reviewer writes "it is probable that [Takaki's] theory will require modification; that error of diet will be admitted to occupy the second place [i.e. second after some micro-organism or toxic agent] instead of the first in the order of causative agents". (1887, ii: 233). Takaki's theory seems not even to have been particularly popular in Japan: his original report provoked a dubious, if not hostile, reaction when it was first presented (Sei-i-Kwai med. J., 1886, 5: 12-16, 27-30) and there are indications that it did not grow in popularity (Lancet, 1904, ii: 1513). According to Williams (op. cit., note 6 above, p. 35) "Takaki's theory ... was untenable ... mainly because it was the general medical opinion that disease must have a positive cause, for example, a germ or toxin, or in other words that a deficiency would not provoke a disease." In a later discussion of beriberi, Takaki observed that "the pathological changes occurring in nerves, muscles, etc., are the result of inability of the tissues to repair the waste owing to the insufficiency of nitrogenous substances in the food and the above changes aie further aggravated by the presence of the large quantity of carbohydrates in the food." (Takaki, op. cit., note 1 above, p. 1371.) There is no trace of this idea in Takaki's original publications and its inclusions in this later report may reflect some wavering in the face of the general opposition he encountered. 
begun. In 1835, John G. Malcolmson observed that "the comparative cheapness of all kinds of grain in the Circars, and the easy circumstances of many of the native soldiers who suffered, are fatal to any supposition of the disease depending on deficient and unhealthy diet." ${ }^{\circ 0}$ By 1880 it was common knowledge that those who contracted beriberi often ate more and a better range of foods than those who did not. ${ }^{61}$ Moreover, populations that seemed especially vulnerable to beriberi were often living amid a larger population that remained healthy, and the only apparent dietary difference between the two groups was that the larger and immune population regularly consumed less protein. ${ }^{62}$ Finally, specific cases were known in which beriberi appeared among persons who were living almost entirely on protein. ${ }^{63}$ It was impossible to reconcile these facts with Takaki's theory. These and similar facts continued to count as evidence against dietary theories of beriberi until after the turn of the century. Unfortunately, the argument based on these observations regularly seemed stronger than it really was. Notice how Braddon summarized the argument in his own extensive study of the disease: against those who hold that a deficiency of nitrogen or fat causes beriberi one can cite "several instances in which outbreaks of beriberi happened, and yet there was no deficiency of nitrogen or of fat, or of any other proper component of diet". ${ }^{64}$ Braddon was obviously assuming that all proper components of diet were known; only under this assumption could he conclude that beriberi sometimes appeared where there were no deficiencies of any kind. By challenging this unwarranted assumption, it ultimately became possible to reconcile Takaki's observations with the well-established epidemiological facts. One needed only to realize that there were unknown but essential nutrients which, when lacking, resulted in beriberi.

Because the deficiency theory seemed incompatible with the facts, most early observers favoured other explanations for beriberi. Perhaps the most popular of the alternative theories was that it was "miasmatic" or "malarial". Early observers noted important epidemiological similarities between beriberi and malaria. These similarities were emphasized even by persons who did not espouse the miasmatic concept. ${ }^{65}$ William Anderson, among the earliest western writers to investigate beriberi

${ }^{\infty}$ Quoted in Hirsch, op. cit., note 27 above, p. 592.

'1 Ibid., p. 592f; Rupert, op. cit., note 52 above, p. 509; and Anderson, op. cit., note 52 above, p. 24, all used this argument before Takaki even began his work.

22 Hirsch, op. cit., note 27 above, pp. 592f. In Japan, for example, beriberi was most prevalent in the sea ports where fish was most abundant. In the East Indies, military garrisons contracted the disease while their servants (who ate less meat) did not. Rupert, op. cit., note 52 above, pp. $509 f$.

68 Hirsch, op. cit., note 27 above, quotes a Dutch observer, Overbeck de Meijer, who said "whenever beriberi appears among a ship's company, it is always in consequence of their having to live exclusively on salt meat."

"4 Braddon, op. cit., note 1 above, p. 39 (my italics). Here is another example: Hamilton Wright reported that prisons at Kuala Lumpur temporarily adopted diets based on those used in the Japanese Navy in 1884. The diet was "well balanced and generous" but beriberi still appeared. "This is conclusive proof that on a diet qualitatively and quantitatively correct beriberi is, nevertheless, contracted. It positively eliminates diet regarded as diet as a factor in the causation of the disease." (An inquiry into the etiology and pathology of beriberi, Studies from the Institute for Medical Research, Federated Malay States, Singapore, Kelly and Walsh, 1902, pp. 37, 56). Patrick Manson uses the same argument but with a slightly more guarded conclusion in 'The etiology of beriberi', Trans. epidem. Soc., 1901-2, 21 : 1-17, p. 9.

${ }^{65}$ E.g. Hirsch, op. cit., note 27 above, pp. 596-601. 


\section{K. Codell Carter}

in Japan, noted that most Japanese doctors "believe that the complaint is caused by some poisonous emanation from the soil." He went on to list similarities between beriberi and malaria, and he concluded that the disease is most likely due to "the existence of an atmospheric poison". ${ }^{68}$ The Lancet review of Takaki's work emphasized that "the majority of observers ... have been inclined to attribute [beriberi] ... to a specific poison which is generated in the soil under certain insanitary conditions of local origin, and finds its way into the human body by means of the atmosphere, and perhaps of the food and drinking water also." The review continues by observing that, Takaki's work notwithstanding, "the weight of evidence is still in favour of the miasmatic hypothesis". ${ }^{67}$ As microbiology became more prominent, hope grew that beriberi would join the list of diseases that had been explained by this science. Various researchers sought (and generally found) the responsible microorganism, ${ }^{68}$ and numerous theories were developed linking specific organisms with beriberi. Hamilton Wright attributed the disease to an organism that enters the body by the mouth, and produces a toxin in the pyloric end of the stomach. ${ }^{99}$ Herbert Durham concluded that the disease is similar to diphtheria and that it is communicated from person to person by fomites. ${ }^{70}$ Patrick Manson proposed that beriberi is a form of intoxication, not unlike alcoholism, in which a toxin, manufactured outside the body (probably by micro-organisms) is introduced into the body (probably through air). ${ }^{71}$ Researchers could seldom agree which micro-organism was the cause of beriberi, but few seriously doubted that there was one. In $1897 \mathrm{M}$. H. Spencer wrote: "Little doubt . . . remains that [beriberi] is a germ-borne disease and that the micro-organism which is the cause of it has a specially toxic influence upon the peripheral nerves."72

III

In 1883 C. A. Pekelharing and A. Winkler were sent to Java by the Dutch government to study beriberi. They took with them, as an assistant, Christiaan Eijkman, a microbiologist who had studied in Berlin under Robert Koch. ${ }^{78}$ Eijkman's specific

${ }^{66}$ Anderson, op. cit., note 52 above, p. 19.

${ }^{67}$ Lancet, 1887, ii: 233 f.

68 For example, Glockner identified an amoeba, Fajardo a haematozoon, Pereira a spherical micro-organism, Durham a looped streptococcus, Lacerda a polymorphous ascomycete, Taylor a spirillum, Pekelharing and Winkler a staphylococcus, Thomas the anchylostomum duodemale, Nepveu a stepto bacillus, Rost a diplobacillus, and Dangerfield an areobic micrococcus. There were many others. For a survey of the literature down to 1894 see Scheube, op. cit., note 44 above, pp. 176-191.

69 Wright. op. cit., note 64 above, p. 58.

${ }^{70}$ Herbert E. Durham, 'Notes on beriberi in the Malay peninsula and on Christmas Island', J. Hyg., Camb., 1904, 4: 112-155.

${ }^{11}$ Manson, op. cit., note 64 above, pp. 12-16.

72 M. H. Spencer, 'Notes on beriberi as observed at the Seamen's Hospital, Greenwich', Lancet, 1897, i: $30-32$, p. 32. Through the first decade of the twentieth century this continued to be the most common view. Most of the standard medical texts of the period treated beriberi as infectious. (Osler and McCrae, op. cit., note 14 above, vol. 3, pp. 29-41; Allbutt and Rolleston, op. cit., note 14 above, pp. 615-643; Patrick Manson, Tropical diseases, 4th ed., London, Cassell, 1907, pp. 367-376; and T. K. Monro, Manual of medicine, 3rd ed., London, Baillière, Tindall \& Cox, 1911, p. 182). Discussion at meetings of the British Medical Association also favoured strongly an infectious explanation (Br. med. J., 1905, ii: 1095-1100, 1287-1289).

73 Williams, op. cit., note 6 above, p. 39. 


\section{The germ theory, beriberi, and the deficiency theory of disease}

instructions in travelling to Java were to find the organism responsible for beriberi. ${ }^{74}$ When Pekelharing and Winkler returned to Europe, they reported that the disease was definitely parasitic in origin, but that they had not yet conclusively identified the agent. ${ }^{75}$ Eijkman, however, remained in Java as director of a microbiological laboratory that was connected with a military hospital. While there he made two important discoveries that led to much of the empirical foundation for the deficiency theory of disease. For years, dogs, rabbits, guinea pigs, and monkeys had been used by microbiologists in beriberi research. Eijkman was using chickens in his laboratory and, while he does not make this explicit, it seems likely that they were intended for beriberi research. Eijkman's first important discovery was that under certain conditions, chickens spontaneously contracted a disease whose symptoms and histological features were very like those traditionally connected with beriberi. Eijkman reported that he made this discovery, quite by accident, when the chickens began to show signs of polyneuritis. ${ }^{76}$ The chickens were examined carefully and no pathological organisms were found; Eijkman was unable to infect healthy chickens by exposure to those suffering from polyneuritis. In investigating, Eijkman discovered that whereas the chickens at the laboratory were generally fed a low-grade uncooked rice, it happened that for some weeks they had been fed surplus cooked rice from the hospital kitchen. His second important discovery was that while the ordinary chicken feed was unpolished rice, the kitchen rice was polished. ${ }^{77}$ In a few trials Eijkman convinced himself that consumption of polished rice was responsible for the inception of polyneuritis gallinarum, as he called the chicken disease. Without assuming that polyneuritis gallinarum was etiologically identical to beriberi, Eijkman sought to discover whether beriberi was also correlated with the consumption of polished rice.

There were three ways in which rice was commonly prepared for human consumption. (1) From harvesting, the rice could be milled immediately. In this case, both outside and inner husks were generally removed, leaving only the white grain. This rice was called uncured, polished, or decorticated rice. (2) In some areas newly harvested rice was soaked, steamed, and dried before milling. In this case the milling process usually left some of the inner layers of husk, called pericarp, and certain light brown inner coverings of the grain. ${ }^{78}$ This rice was called cured or unpolished

7 Ibid., p. 19.

${ }^{76}$ For a report of their findings see Lancet, 1889, i: 892f, 941 .

"Christiaan Eijkman, 'Eine beriberi-ăhnliche Krankheit der Hühner', Virchows Arch. path. Anat. Physiol., 1897, 148: 523-532, p. 525.

"1 Ibid. There are various versions of the sequence of events leading to these discoveries. The following account is from Eijkman's obituary notice in the Lancet (1930, ii: 1097f). "Eijkman's original research in connection with beriberi began in a curiously accidental way. He wished to carry out certain investigations on fowls, and in order to economise on their food he fed them on scraps from the wards of the military hospital to which he was attached. On these scraps, which consisted chiefly of cooked, polished rice, the fowls developed paralyses, whose nature was at first obscure. A clue thereto was unintentionally given by a newly appointed director of the hospital, who refused to let Eijkman feed his fowls any longer on scraps from the wards. Henceforth they were fed on gaba (rice still in the husks) and on this diet they recovered."

78 "Parboiling toughens the grain and reduces the amount of breakage in milling .... In parboiling, some of the vitamins are driven into the endosperm and by gelatinizing the starch of the outer layers seals the aleurone layer and the scutellum, so that they are not readily removed in milling. Milled parboiled rice contains two to four times as much thiamine and niacin as milled raw rice and rather more riboflavin." D. H. Grist, Rice, 4th ed., London, Longmans, 1965, p. 404. 


\section{K. Codell Carter}

rice. (3) In some primitive areas, the rice was not machine milled at all, but was stored unhusked and then pounded and winnowed just prior to eating. ${ }^{79}$ Local custom, ethnic origin, and economic status were among the factors determining which kind of rice an individual ate. In Java, prison inmates were usually fed whichever form of rice was commonly consumed by the local population; in twenty-seven prisons, inmates ate unpolished rice, in seventy-four others the rice was decorticated to some extent. This provided an ideal opportunity for determining whether beriberi was correlated with the consumption of decorticated rice. Eijkman's colleague, A. G. Voderman, who was then a Civil Medical Inspector, conducted surveys of the prisons throughout Java. The preliminary results were astonishing: of nearly 300,000 prisoners, only one in 10,000 of those who ate unpolished rice had beriberi, while one in thirty-nine of those who ate polished rice had the disease. ${ }^{80}$ These results exhibited dramatically the correlation between the incidence of beriberi and the consumption of a particular kind of rice. Within a few years, studies of other populations confirmed these results. Braddon noted that in the Malay States, the Chinese, who ate polished rice, were seriously afflicted with beriberi; Tamils, who ate unpolished rice, and native Malays, who ate rice that was not mechanically milled, were almost free from the disease. ${ }^{81}$ Both Voderman's and Braddon's evidence was demographic and it was, therefore, subject to no strict controls. Eijkman's studies on fowl could yield only analogical arguments that many found unconvincing. ${ }^{82}$ Toward the end of the decade, however, William Fletcher (1907) and Henry Fraser and Thomas Stanton (1909) published important studies on small and carefully controlled groups. ${ }^{83}$ These controlled studies probably did more than anything else to persuade medical opinion that decorticated rice was connected with beriberi. ${ }^{84}$ By 1910 the evidence was clear enough for a meeting of the Far Eastern Association of Tropical Medicine to adopt a motion stating: "That in the opinion of this association sufficient evidence has now been produced in support of the view that beriberi is associated with the continuous consumption of white (polished) rice as the staple article of diet. . .."85

There are unmistakable similarities between the prevailing medical opinion of scurvy in 1830 and the motion regarding beriberi that was adopted by the Far Eastern

${ }^{70}$ Brief discussions of these techniques of rice production appear in Braddon, op. cit., note 1 above, pp. 137-150; and in Fletcher, 'Rice and beriberi', Lancet, 1907, i: 1776-1779, p. 1776.

${ }^{80}$ Christiaan Eijkman, 'Ein Versuch zur Bekämpfung der Beriberi', Virchows Arch. path. Anat. Physiol., 1897, 149: 187-194, p. 187. Other reports were published independently by Voderman.

s1 Braddon, op. cit., note 1 above, pp. 150-198. Braddon also cites some evidence from areas outside the Malay peninsula.

82 "The favourite view of most physicians who knew of [Eijkman's] work at all, was to dismiss the matter with the assertion that polyneuritis in fowls had no relation to human beriberi." Williams, op. cit., note 6 above, p. 14 .

8s Fletcher, op. cit., note 79 above, pp. 1776-1779; Henry Fraser and Thomas Stanton, 'An inquiry concerning the etiology of beriberi', Lancet, 1909, i: 451-455.

s4 Williams, op. cit., note 6 above, p. 48.

os $\mathrm{Br}$. med. J., 1910, i: 999-1000. It is interesting to compare these views expressed by researchers in Asia with the more conservative opinions in Europe. At the 16 April 1909 meeting of the Society of Tropical Medicine and Hygiene, a clear majority were against the "rice theory". However, two years later, at a meeting of the Society held on 17 November 1911, the consensus of opinion favoured a dietary theory for beriberi. At this latter meeting Patrick Manson, admitting that his ideas about beriberi "belong to a past age", was practically alone in expressing serious reservations about the dietary theory. (Trans. Soc. Trop. Med. Hyg., 1908-9, 2: 236-256; 1911-12, 5: 81-90). 


\section{The germ theory, beriberi, and the deficiency theory of disease}

Association of Tropical Medicine in 1910. Both focus on an empirical correlation between the respective disease and particular dietary patterns. In both cases there was clear evidence that the disease could be effectively controlled by specific changes in those patterns. The remarkable difference is that, whereas the empirical understanding of scurvy effectively ended all new study, everyone seems to have regarded the empirical correlation between beriberi and polished rice as interesting only insofar as it pointed the way toward a deeper theoretical understanding of the disease. Why was there this difference? The answer must be found in the germ theory. The germ theory provided a causal explanation for many diseases, but it did much more. First, it explained a wide range of facts (facts about the spread of disease, about certain kinds of immunity, etc.) in terms of the natural behaviour of micro-organisms. In many cases, these facts had been known long before the germ theory was promulgated, but they remained unexplained and unconnected. Second, whereas particular diseases had been regarded as collections of symptoms, the germ theory treated each set of symptoms only as the clinical manifestation of a disease. This led to new classifications of diseases and it made diagnosis much more definitive. In these ways, the germ theory systematized certain areas of medical knowledge. Consequently, knowledge of these diseases explained by the germ theory was more fundamental, more coherent, more scientific. Thus, the germ theory provided a new standard for judging the understanding of any disease. Against this standard, disorganized collections of facts were no longer adequate. This was no less true when those facts included -as they did for scurvy, for example-completely reliable and correct methods for preventing and curing the disease. Before the germ theory, the understanding of scurvy constituted a paradigm and an ideal to be emulated by medical observers seeking to control other diseases; after the germ theory, that understanding was recognized as partial and fragmentary. Thus, Wilhelm Koch did not contravert what was known of the relation between scurvy and the lack of fresh vegetables, but he sought an explanation for that relation and for other disconnected empirical facts about the disease. Shall we say that Koch's investigation (or the theory that motivated it) obstructed the understanding of scurvy? Eijkman was a microbiologist. Fletcher, Fraser, and Stanton were medical doctors who specialized in pathology; all did significant original work in microbiology ${ }^{86}$ These men subscribed to the standard for theoretical comprehension that had been established by the germ theory. Given that standard, the empirical relation between beriberi and the consumption of polished rice could not constitute an adequate understanding of the disease. No matter how well documented it may be and regardless of whether it enabled doctors to control beriberi, the correlation required a theoretical explanation. Prior to the germ theory -when control of symptoms still constituted the paradigm for understanding any disease-researchers could not have recognized the inadequacy of their understanding of beriberi. Thus, far from constituting an obstacle to the understanding of deficiency diseases, the germ theory provided the most important incentive for studying them. Numerous theories were proposed to explain the etiology of beriberi and, of

\footnotetext{
${ }^{86}$ See the obituary notices for these men in the Lancet, 1930, ii: 220 (Fraser); 1938, i: 349 (Stanton); ii: 808 (Fletcher).
} 


\section{K. Codell Carter}

course, most of these were derived in one way or another from the germ theory. ${ }^{87}$ Braddon proposed that polished rice was the locus within which a toxin was created by micro-organisms and by which it was transferred into the potential victim..$^{88}$ Eijkman's original hypothesis was also a version of the toxic theory: "under assumption that all polyneuritis ultimately seems to be intoxication, we must assume that the starch in these cases carries a poison or that from it-either in the alimentary canal (possibly under the influence of a micro-organism) or in the nerves-a poison is produced through the chemical process of metabolism. In the pericarp [Silberhäutchen] of the grain, then, the material(s) would be present, through which the poison is, in some way, made harmless or, perhaps, its creation is prevented." 89 An essentially correct theoretical understanding of the situation was suggested by Gerrit Grijns, a microbiologist who succeeded Eijkman as director of the pathology laboratory in Batavia. In an article published in 1901 Grijns proposed that there may be some unknown ingredient in the pericarp whose absence resulted in beriberi.90 In the article he asserted that recent developments were leading away from the idea that beriberi was infectious. Moreover, in his own experiments he had induced polyneuritis in chickens by feeding them concentrated protein (cooked horse meat) and this, he felt, counted heavily against Eijkman's hypothesis. The most likely conclusion seemed to be "that there are various natural foodstuffs that cannot be missed without particular damage in the peripheral nerves". .1

Grijns' hypothesis, which did not appear in a readily accessible source, seems not to have received prompt attention; for the next few years most researchers continued to favour a toxic or infectious explanation. However, it is misleading to attribute this to "preoccupation of scientists and doctors with positive infecting agents". In the first place, there were persuasive arguments against dietary explanations of beriberi. In spite of these arguments, beriberi researchers remained open to alternative considerations. Pekelharing, who was a particularly influential early advocate of an infectious explanation for beriberi, subsequently performed pioneering studies proving the inadequacy of the known macronutrients. ${ }^{22}$ Fletcher emphasized that his findings were compatible with a variety of causal explanations. ${ }^{93}$ Fraser and

" For a brief summary of some of the false theories see Williams, op. cit., note 6 above, pp. $14 f$.

88 Braddon, op. cit., note 1 above, pp. 39-48.

2o Eijkman, op. cit., note 76 above, pp. 529 .

'0 Gerrit Grijns, 'Over polyneuritis gallinarum', Geneesk. Tijdschr. Ned.-Indië, 1901, 41: 3-49.

11 Ibid., p. 45.

92 In 1905 Pekelharing wrote that there was an unknown substance in milk and in certain other foods "which even in very small quantities is of paramount importance to nourishment. If this substance is absent, the organism loses its power properly to assimilate the well-known principal parts of food, the appetite is lost and with apparent abundance the animals die of want." Quoted in McCollum, op. cit., note 5 above, p. 207. Pekelharing and Eijkman worked together in Java as members of the beriberi research commission, and, at the time Pekelharing published the above conclusion, he and Eijkman were both teaching at the University of Utrecht. Pekelharing's animal experiments must have been suggested by Eijkman's work, and Eijkman, in turn, must have seen the implications of Pekelharing's experiments.

os Fletcher (op. cit., note 79 above, p. 1778) notes that, compatible with his findings, the cause of beriberi could be either "(1) a poison contained in the rice; (2) deficiency of proteid matter, the disease being due to nitrogen starvation; or (3) uncured rice does not form a sufficiently nutritive diet and renders the patient's system specially liable to invasion by a specific organism, which is the cause of beriberi." In fact, Fletcher's findings were also compatible with the actual cause of beriberi, which was not mentioned in his list. 


\section{The germ theory, beriberi, and the deficiency theory of disease}

Stanton carefully avoided explicit commitment to any particular theory in their original publications. Even Eijkman, who has been said to have been victimized by the preconceptions of the germ theory, abandoned his toxin hypothesis by $1906 . .^{94}$ Second, through the first decade of the twentieth century, explanations of beriberi that were based on the germ theory continued to provide important experimental results. Fletcher and Braddon both conducted their demographic studies in connexion with infectious theories of the disease. In testing Eijkman's toxin hypothesis, Grijns obtained important results from animal experiments. ${ }^{95}$ Because he believed that the pericarp contained a natural antitoxin that neutralized the harmful influence of the starchy rice grain, Eijkman began an active chemical investigation in the effort to isolate the antitoxin. He was able to show that an aqueous extract from the rice polishings would cure polyneuritis gallinarum; he also showed that when foods were heated above $120^{\circ} \mathrm{C}$ they lost their effectiveness in preventing and curing the disease. ${ }^{96}$ These were significant results that profited later researchers. ${ }^{97}$ Science advances as hypotheses-both true and false-are tested experimentally. A given hypothesis becomes a barrier to progress only when it ceases to suggest profitable new experiments or when those who espouse it do not remain open to alternative hypotheses. Admittedly Eijkman was somewhat slow in recognizing the truth, but surely it is an exaggeration to claim that Eijkman's hypothesis, based on the germ theory, "proved a major barrier to the recognition and study of deficiency diseases".

The success achieved by Eijkman and Grijns suggested profitable avenues of investigation for researchers working on a different disease. Beginning in 1894, crews on Norwegian ships began to suffer from a disease some of whose symptoms were similar to those of beriberi; the disease was called ship-beriberi. In 1902 a Norwegian research commission reported that ship-beriberi was a non-infectious intoxication from tainted foods. ${ }^{98}$ In the same year, Alex Holst visited Grijns in Batavia; Grijns showed him the experiments he was performing on fowls. ${ }^{99}$ Holst was much impressed with the work of Eijkman and Grijns; he decided to adopt similar techniques in his own study of ship-beriberi. He tried to induce the disease in pigeons and chickens and later, after having been joined by Theodor Frölich, in guinea pigs. ${ }^{100}$ The results of carefully controlled feeding experiments were curious: while Holst and Frölich were trying to study ship-beriberi, the guinea pigs regularly contracted a disease that bore every similarity to scurvy. Holst and Frölich did not

94 "One must regard Eijkman as primarily a bacteriologist who, during the period of his work in Java, was to some extent a victim of the preoccupation shared by most medical research men of that post-Pasteur era, that disease can only be caused by a positive agent such as an infecting organism or a toxin" (Williams, op. cit., note 6 above, p. 40). In 'Uber Ernahrungspolyneuritis', Arch. Hyg. Bakt., 1906, 58: 150-17.0, p. 152, Eijkman observes that beriberi is caused by a diet of starchy food "although there is no ground for assuming that it contains a nerve poison".

${ }^{95}$ Animal experiments of the kind initiated by Eijkman and Grijns were so important in the study of deficiency diseases that, according to Williams, "proof of the chemical nature of the missing substance could never have been achieved" without them (Williams, op. cit., note 6 above, p. 36).

9ijkman, op. cit., note 94 above, pp. 155-170.

97 Funk, op. cit., note 34 above, p. 343.

os For a report of the Commission's findings, see Lancet, 1903, i: 378. The Commission reported that tropical beriberi was caused by tainted grain, and that ship-beriberi was caused by tainted meat.

'P Alex Holst, 'Experimental studies relating to ship-beriberi and scurvy, part I', J. Hyg., Camb., 1907, 7: 619-633.

100 Holst and Frölich, op. cit., note 33 above, pp. 634-671. 


\section{K. Codell Carter}

verify that similar diets would induce scurvy in humans, but they did mention that earlier evidence connected scurvy with deficient diet, and that scurvy and beriberi often appeared together. ${ }^{101}$ They also cite B. Nocht, a German observer, who had argued that it would be helpful to treat ship-beriberi as a form of scurvy. In their original publication, Holst and Frölich did not endorse any specific theories about the cause of beriberi or of ship-beriberi. Subsequent developments revealed clearly, however, that they regarded these diseases (like scurvy) as deficiency diseases. For example, at a discussion of the Society of Tropical Medicine and Hygiene, Holst noted that on identical diets, chickens contracted beriberi, guinea pigs contracted scurvy, and pigs contracted both diseases. ${ }^{102}$ As a result of their publications, beriberi, scurvy, and ship-beriberi were all seen as causally linked to deficient diets and, therefore, as theoretically linked to one another.

In 1910 Fraser and Stanton showed that the substance that prevented beriberi was soluble in strong alcohol, and that the effectiveness of a given grain in combating beriberi was correlated with the amount of phosphorus it contained. ${ }^{103}$ This led Schaumann, who was associated with Nocht, to propose that a wide range of diseases may be due to deficiency of phosphorus. "According to all appearances there is a series of diseases that are similar in etiology to beriberi. For scurvy this is, through numerous observations, well founded. To this group of diseases with similar etiology also belong, apparently, Barlow's disease, rickets, osteomalacia, and possibly also pellagra. For all these diseases the opinion is clearly suggested that they are the result of a shortage of phosphorus." 104 Schaumann's hypothesis was a step backwards insofar as he believed that all these diseases resulted from deficiency of the same nutrient. By obtaining a purer specimen of the crucial ingredient in rice husks, Casimir Funk was soon able to show that beriberi, at least, was not due to phosphorus deficiency. ${ }^{105}$ However, Schaumann did advance matters by classifying pellagra and rickets with scurvy and beriberi. Unfortunately, his 397-page treatment of beriberi, the source of the preceding quotation, contains no discussion either of pellagra or of rickets, and in his previous and subsequent publications there is no mention of either disease. ${ }^{106}$ For Schaumann, classifying pellagra and rickets as deficiency diseases seems to have been as much a lucky guess as a rational inference. ${ }^{107}$

101 Ibid., pp. 666-669.

102 Alex Holst, 'The etiology of beriberi', Trans. Soc. Trop. Med. Hyg., 1911-12, 5: 76-80, p. 79.

108 Henry Fraser and Thomas Stanton, 'The etiology of beriberi', Lancet, 1910, ii: 1755-1757.

104 Schaumann, op. cit., note 51 above, p. 369.

105 Funk first reported this finding as a discussant in a meeting of the Society of Tropical Medicine and Hygiene. (Trans. Soc. Trop. Med. Hyg., 1911-12, 5: 87.)

106 Schaumann, 'Die Ätiology der Beriberi', Arch. Schiffs- u. Tropenhyg., 1908, 12: Beiheft 5; and 'Further contributions to the etiology of beriberi', Trans. Trop. Soc. Med. Hyg., 1911-12, 5: 59-75.

${ }^{102}$ His (unstated) grounds for so classifying the diseases may have been the following: pellagra, like beriberi, was epidemiologically connected with consumption of a particular grain (corn). Early observers attributed the disease to a deficient or one-sided diet, and they noted symptomatic similarities between pellagra and scurvy. Numerous unsuccessful attempts had been made to explain the disease as an intoxication or as an infection. To those engaged in beriberi research, these similarities must have been highly suggestive. The situation was somewhat different in the case of rickets. There was a long-standing opinion that rickets was diet-related. By the end of the nineteenth century, a theory was originated in Germany that attributed rickets to a lack of elemental phosphorus. (MoCollum, op. cit., note 5 above, p. 272.) This notion became sufficiently popular that it was 


\section{The germ theory, beriberi, and the deficiency theory of disease}

By 1910 several lines of work were converging rapidly on the deficiency theory of disease. First, epidemiological studies (Takaki, Voderman, Braddon, Fletcher, Stanton and Fraser) and animal experiments (Eijkman, Grijns, Holst and Frölich) had exhibited a connexion between certain diets of milled grain and various distinctive disorders. Second, chemical studies (Eijkman, Fraser and Stanton, Funk) had isolated and characterized with fair precision the particular ingredient in rice polishings that would prevent and cure some of these disorders. Third, an important negative result was that after thirty years of searching, microbiologists could not agree in identifying a particular micro-organism that was causally responsible for any of the diseases in question. Given the importance of the germ theory at this time, it would have been difficult for any deficiency hypothesis to have been accepted as the ultimate explanation for beriberi without this negative result. Fourth, theoretical developments (Grijns, Holst and Frölich, Nocht, Schaumann) had generated the elements of a perfect conceptual framework within which most of the observations could be explained. Finally, we must consider one line of research which, although of relatively minor importance in the original formulation of the deficiency theory, proved to be of great significance in its subsequent elaboration. Through the nineteenth century, various experiments were performed to test the influence on animals of simplified diets-often diets consisting of one isolated food substance. For the most part these experiments were not connected with the study of any particular disease, and often they had relatively little impact on subsequent medical thought. By the beginning of the twentieth century, numerous more systematic experiments of this kind were performed in examining the processes of protein synthesis. ${ }^{108}$ Various experimenters discovered that the macronutrients alone would not support normal growth and development of animals. In 1906 F. Gowland Hopkins, who was a leader in these experiments, concluded that "there are many minor factors in all diets of which the body takes account. In diseases such as rickets, and particularly in scurvy, we have had for long years knowledge of a dietetic factor; but though we know how to benefit these conditions empirically, the real errors in the diet are to this day quite obscure."109 Such conclusions provided collateral support for the deficiency concept as an explanation for beriberi. Taken together all of these relatively independent lines of work constituted the basis for the deficiency theory of disease-it was necessary only that they be assembled correctly.

The first publication in which all these strands were finally assembled was Casimir Funk's The etiology of the deficiency diseases published in 1912. Funk announcedsomewhat prematurely - the isolation of a highly concentrated form of the protective substance for beriberi; he proposed that it be called vitamine. ${ }^{110}$ Funk identified

reflected in therapies recommended by British medical texts in the first decade of the twentieth century. It seems likely that this conception of rickets influenced Schaumann in the formulation of his hypothesis.

${ }^{108}$ McCollum, op. cit., note 5 above, pp. 207-210.

${ }^{100}$ F. Gowland Hopkins, 'The analyst and the medical man', Analyst, Lond., 1906, 31: 385-397, pp. $395 f$.

110 Funk, op. cit., note 34 above, p. 342. The word 'vitamine' remained in use until 1920 by which time it had become clear that many of the substances thus identified were not organic bases. Jack Cecil Drumond then proposed that the name be changed to 'vitamin' in order to bring the termin- 


\section{K. Codell Carter}

beriberi, polyneuritis in birds, epidemic dropsy, scurvy, experimental scurvy in animals, infantile scurvy, ship-beriberi, pellagra, and (toward the end of his article) rickets, as deficiency diseases. He stated clearly that these different diseases are due to different deficiencies. Funk, in contrast to Schaumann, provided some justification for including pellagra and rickets in this classification. Funk noted that about twenty years of experimental work had been necessary to establish that these various diseases were caused by a deficiency of essential nutrients. He admitted that this view was still not generally accepted, but he claimed that there was enough evidence "to convince everybody of its truth, if the trouble be taken to follow step by step the development of our knowledge on this subject". ${ }^{111}$ Subsequent research has confirmed most of Funk's opinions and vindicated most of the arguments he provided in their support. After his paper, additional work on the deficiency diseases can be thought of as the elaboration of an existing theory rather than as the creation of a new one.

\section{SUMMARY AND CONCLUSIONS}

We began by citing numerous writers who treat the germ theory only as an obstacle that delayed recognition and study of the deficiency diseases. But our investigation has revealed that this point of view does not give due consideration to important facts. Deficiency diseases were recognized as such for half a century before the germ theory was promulgated. In British practical medicine, scurvy was continuously thought of as a deficiency disease at least from the beginning of the nineteenth century. However, early in that century, work on scurvy stagnated; there was little interest in a more fundamental understanding of the disease until the dietary explanation was challenged (but never surmounted) by explanations based on the germ theory. During this period, beriberi became prominent. Its etiology was first understood by microbiologists and orthodox pathologists who, in the relatively short period of about thirty years, developed a new theory of disease that explained not only beriberi but also scurvy, rickets, pellagra, and various other illnesses. There is no doubt that the germ theory misled many of those who investigated beriberi, but it also suggested demographic studies and animal and chemical experiments that were crucial for a full understanding of the disease. Moreover, the germ theory provided a new standard for theoretical understanding of disease. Against this standard, the understanding of scurvy was recognized as inadequate, and new studies were undertaken. Thus, the germ theory revived interest in scurvy and it motivated researchers to seek a theoretical understanding of beriberi. Without this motivation, work on beriberi might have stagnated once the disease could be controlled, just as work on scurvy had stagnated about a century earlier. In this sense, the germ theory contributed directly to the development of the deficiency theory of disease. In view of these facts, treating the germ theory only as a barrier to the study of deficiency diseases seems, at the very least, to reflect a serious lack of historical perspective.

ology into harmony with standard chemical usage. ('The nomenclature of the so-called accessory food factors (vitamins)', Biochem. J., 1920, 14: 660.)

${ }^{111}$ Funk, op. cit., note 34 above, p. 341. 